\title{
Implementasi Program Pembinaan Usaha Mikro Kecil Menengah Sektor Kuliner di Kota Palembang
}

\section{Implementation of the Culinary Sector Micro Small Medium Enterprises Development Program in Palembang City}

\author{
Dwi Mirani1 $^{*}$, Martina², Januar Eko Aryansah ${ }^{3}$ \\ Jurusan Ilmu Administrasi Publik, Fakultas Ilmu Sosial dan Ilmu Politik, \\ Universitas Sriwijaya, Indonesia
}

Disetujui: November 2021; Direview: April 2021;Diterima: Mei 2021

\begin{abstract}
Abstrak
Penelitian ini bertujuan untuk mengetahui implementasi program pembinaan pelaku UMKM sektor kuliner di Kota Palembang. Penelitian ini menggunakan metode penelitian kualitatif. Teknik pengumpulan data yang digunakan berupa wawancara mendalam, observasi, studi dokumentasi dan dianalisis dengan teknik triangulasi data. Lokasi penelitian dipilih dengan jumlah lokasi usaha kuliner terbanyak di kota Palembang yang terletak di sentral kampung pempek 26 ilir, sentra kuliner Sekanak, 27 Ilir dan pelaku UMKM 32 ilir serta ilir timur II. Penentuan sampel informan dilakukan secara purposive sampling. Informan dalam penelitian ini adalah Dinas Koperasi dan UKM Kota Palembang, Pelaku Usaha Binaan dan bukan Binaan Dinas Koperasi dan UKM Kota Palembang, dan Komunitas UMKM Kota Palembang. Hasil penelitian menunjukkan implementasi program pembinaan pelaku UMKM sektor kuliner di Kota Palembang cukup baik, namun belum optimal, kondisi ini dapat dilihat dari masih adanya hambatan yang dihadapi dalam implementasinya. Strategi yang dapat digunakan pemerintah untuk mengoptimalkan peran dalam pembinaan antara lain sosialisasi berkelanjutan kepada komunitas pelaku UMKM. Keterlibatan peran multi sektor dalam pelatihan dan pembinaan sektor kuliner, proses dan persyaratan pengajuan kredit modal usaha, dan penambahan jumlah sasaran penerima bantuan kredit, serta riset gabungan antara berbagai pihak dalam mengenalkan inovasi teknologi baru dan menambah sumber daya pelaksana sebagai pendamping dalam program pembinaan.
\end{abstract}

Kata Kunci: Implementasi, Program Pembinaan, UMKM

\section{Abstract}

This study aims to determine the implementation of the development program for SMEs in the culinary sector in Palembang City. This study used qualitative research methods. Data collection techniques used in the form of in-depth interviews, observations, documentation studies and analyzed by data triangulation techniques. The research location was chosen with the highest number of culinary business locations in the city of Palembang, which is located in the center of the village of Pempek 26 ilir, the culinary center of Sekanak, 27 Ilir and SMEs 32 ilir and ilir east II. Determination of the sample of informants is done by purposive sampling. Informants in this study were the Office of Cooperatives and SMEs of Palembang City, Business Actors who were fostered and not assisted by the Office of Cooperatives and SMEs of Palembang City, and the MSME Community of Palembang City. The results showed that the implementation of the culinary sector MSME development program in Palembang City was quite good, but not optimal, this condition can be seen from the obstacles faced in its implementation. Strategies that can be used by the government to optimize the role in fostering include sustainable socialization to the community of MSME actors. The involvement of multi-sectoral roles in training and fostering the culinary sector, the process and requirements for applying for business capital loans, and increasing the number of target recipients of credit assistance, as well as joint research between various parties in introducing new technological innovations and adding implementing resources as companions in the coaching program.

\section{Key words: Implementation, development program, MSMEs}

How to Cite: Mirani, D., Martina dan Aryansyah, E.J (2021). Implementasi Program Pembinaan Usaha Mikro Ke Menengah Sektor Kuliner di Kota Palembang. PUBLIKAUMA: Jurnal Ilmu Administrasi Publik UMA, Vol 9, (1): 38-4 ${ }^{*}$ Corresponding author:

E-mail: 


\section{PENDAHULUAN}

Krisis ekonomi yang menimpa dunia telah menyadarkan para pengambil kebijakan untuk kembali mencermati model pembangunan ekonomi yang benar-benar memiliki stuktur yang kuat dan dapat bertahan dalam situasi apapun (Dewi dan Nasution \& Hakim, 2013). Begitu juga di Indonesia. Dalam kondisi ini, pelaku ekonomi yang cukup kuat dapat bertahan menghadapi krisis ialah sektor UMKM. UMKM dianggap lebih tangguh sehingga dapat bertahan terhadap krisis ekonomi dan moneter (Hamzah \& Agustien, 2019). Hal ini dikarenakan mayoritas usaha berskala kecil tidak terlalu tergantung pada modal besar atau pinjaman dari luar dalam mata uang asing, sehingga ketika ada fluktuasi nilai tukar perusahaan berskala besar secara umum akan selalu berurusan dengan mata uang asing yang paling berpotensi mengalami imbas krisis (Suci et al., 2017)

Pertumbuhan ekonomi sektor rill Indonesia merupakan sektor utama dalam mengerakkan ekonomi nasional. Menurut data kementerian Koperasi, Usaha Kecil, dan Menengah (KUKM) Tahun 2018 sektor riil yang diwakili oleh Usaha Mikro Kecil dan Menengah (UMKM) telah memberikan kontribusi sebesar 61,1 persen dari pendapatan domestik bruto (PDB) dari total keseluruhan Rp 14.837,4 triliun PDB Indonesia tahun 2018. Selain itu, UMKM juga memberikan kontribusi dari sisi kemampuan menyerap tenaga kerja. Daya serap UMKM menyerap tenaga kerja sebanyak 117 juta tenaga kerja atau $97 \%$ dari daya serap tenaga kerja di Dunia Usaha.

Ditingkat kota dan kabupaten peran UMKM tidak dapat dipungkiri telah banyak membantu peningkatan ekonomi masyarakat, hal ini dikarenakan UMKM merupakan entitas produsen sekaligus konsumen yang cukup besar sehingga uang yang ada dimasyarakat mengalami perputaran dari dan oleh UMKM itu sendiri. Selain itu, UMKM lebih tangguh sehingga lebih tahan terhadap krisis ekonomi dan moneter (Hamzah \& Agustien, 2019)

Pada tahun 2019 menurut data dari Dinas Koperasi dan UKM Kota Palembang terdapat 37.000 UMKM yang terdaftar (Dinas Koperasi \& UKM Palembang, 2019). Mayoritas bergerak di usaha kuliner. Dinas Koperasi dan UKM Palembang sendiri memiliki program pembinaan bagi UMKM namun dari total jumlah UMKM di Palembang tersebut hanya 4.000 UMKM atau hanya sekitar 10,8\% UMKM yang bergabung dalam binaan Dinas Koperasi dan UKM Kota Palembang.

Hasil Evaluasi Dinas Koperasi dan UKM Kota Palembang pada tahun 2019, terdapat beberapa permasalahan yang dihadapi oleh UMKM sehingga UMKM di Kota Palembang sulit berkembang antara lain karena pelaku UMKM mengalami hambatan dalam proses perizinan, disamping itu, banyak UKM yang tidak aktif meskipun sudah dibantu modal usaha tanpa agunan. Di sisi lain, UMKM belum sepenuhnya dapat memanfaatkan teknologi dan sebagian pelaku UMKM terkendala pengecekan Sistem Informasi Riwayat kredit si debitur oleh Bank Indonesia (BI checking) sebagai pengaman penyaluran kredit (Agustin, 2020)

Selain persoalan tersebut, UMKM menghadapi persoalan lain terkait dengan akses permodalan, kualitas Sumber daya manusia yang rendah, dan rendahnya penguasaan teknologi. Namun Demikian, UMKM memiliki daya tahan yang lebih baik terhadap krisis terlepas dari produktivitas yang rendah. Hal ini dikarenakan struktur organisasi dan tenaga kerja UMKM yang lebih fleksibel dalam menyesuaikan dengan perubahan pasar. Daya tahan dan fleksibilitas ini menjadikan UMKM digunakan oleh sebagian besar masyarakat sebagai sumber utama penghidupan(Sugiri, 2020).

Usaha Mikro, Kecil dan Menengah (UMKM), merupakan salah satu industri yang berkembang pesat di Kota Palembang saat ini. Usaha Mikro, Kecil dan Menengah (UMKM) adalah salah satu industri yang mempunyai kemampuan untuk terus berkembang dan dapat bersaing dalam menghadapi persaingan pasar yang ada saat ini, untuk itu dibutuhkan sebuah kebijakan pemerintah untuk membantu 
kelompok masyarakat menyelesaikan persoalan mereka (Indiahono, 2017).

Berdasarkan tingkat produktivitas dan kebutuhan untuk meningkatkan populasi UMKM, maka pembinaan dan pemberdayaan UMKM dalam meningkatkan produktivitas usaha mikro hendaknya mendapat perhatian khusus. Peningkatan kapasitas UMKM melalui program pembinaan diharapkan dapat meningkatkan pendapatan masyarakat dan mengurangi kemiskinan.

Program Pembinaan UMKM merupakan program turunan dari pemerintah pusat melalui Kementerian Koperasi dan UKM yang dilaksanakan oleh pemerintah Kota Palembang dalam hal ini Dinas Koperasi dan UKM. Pembinaan terhadap industri kecil dan menengah dapat dilakukan dengan Pengembangan SDM, Pengembangan Produk dan pengembangan manajemen produksi. Bentuk pembinaan yang dilakukan berupa pemberian bantuan modal, kemitraan dan pelatihan (Trisnawati, 2016).

Kemampuan UMKM untuk bersaing dapat dibuktikan dari terus bertambahnya jumlah UMKM yang ada di kota Palembang. Dari data yang di dapat dari Dinas Koperasi dan Usaha Kecil dan Menengah kota Palembang pada tahun 2016 terdapat 156 UMKM yang menjadi binaan Dinas Koperasi dan Usaha Kecil dan Menengah Kota Palembang, jumlah tersebut mengalami kenaikan pada tahun 2017 yaitu sebanyak 187 UMKM yang menjadi binaan Dinas Koperasi dan Usaha Kecil dan Menengah Kota Palembang.

UMKM di Kota Palembang yang berada di bawah pembinaan Dinas Koperasi dan UKM telah melakukan berbagai program pembinaan UMKM salah satunya program bantuan modal bagi pelaku UMKM dari tahun 2017 sampai sekarang. Program bantuan modal usaha tanpa agunan, masing-masing sebesar 3 juta kepada pelaku UMKM, program tersebut awalnya diberikan kepada 1000 pelaku UMKM, melihat besarnya manfaat program maka jumlah ini akan terus ditingkatkan sesuai dengan kemampuan pemerintah kota. Namun, sampai saat ini Program bantuan dan pembinaan yang dilakukan oleh Dinas tersebut belum sepenuhnya menjangkau
UMKM yang ada di 18 kecamatan di Kota Palembang.

Berdasarkan data UMKM yang terdaftar di Dinas Koperasi dan UKM Kota Palembang tahun 2020 jenis usaha Pempek, Kerupuk, dan Kemplang merupakan jenis usaha yang paling banyak yaitu sebanyak 53 UMKM atau sebanyak 28\%. Sajian makanan khas Palembang dan aneka variannya, tahun 2019 ini menjadi pusat perhatian di Indonesia. Oleh sebab itu, Kota Palembang mencanangkan tema utama pemerintahan kota Palembang menjadi “K0TA KREATIF 2019" pada sub sektor kuliner. Hal ini menjadi alasan bagi penelitian ini untuk mengangkat sektor kuliner sebagai topik penelitian.

Program pembinaan/ pengembangan UMKM telah mengandeng banyak pihak baik pemerintah maupun swasta. Program ini berguna untuk meningkatkan pengetahuan dan wawasan pelaku UMKM (Rakib Muhammad Alyas, 2017). Melihat pentingnya pembinaan bagi UMKM, maka tujuan dari tulisan ini adalah untuk mengetahui Implementasi program pembinaan UMKM khususnya sektor kuliner di Kota Palembang. Sehingga di dapat solusi berupa strategi untuk mengatasi permasalahan yang dihadapi oleh pemerintah Kota Palembang dalam Implementasi Program ini.

\section{METODE PENELITIAN}

Penelitian ini menggunakan metode Kualitatif dengan pendekatan deskriptif. Penelitian ini berlokasi di Kota Palembang dengan melibatkan Instansi Dinas Koperasi dan UKM Kota Palembang yang berperan sebagai pelaksana program pembinaan pelaku UMKM sektor Kuliner di Kota Palembang, lokasi yang dipilih pada awalnya adalah pada sentral kampung pempek, 26 Ilir dan sentra kuliner pempek, 27 Ilir.

Penelitian mengalami penambah-an lokasi disebabkan oleh tidak ditemukannya pelaku UMKM yang mendapatkan pembinaan langsung dari Dinas Koperasi UKM Kota Palembang, hal ini disebabkan oleh kedua sentra tersebut telah mendapat pembinaan dari program corporates sosial responsibility (CSR) dan pembinaan dari Dinas Koperasi dan Usaha Kecil Menengah 
(DISKOPUKM) serta Dinas Pariwisata Provinsi Sumatera Selatan. Oleh karena, untuk mendapatkan informasi tentang pelaku usaha yang mendapatkan pembinaan, lokasi bertambah di kawasan 32 ilir dan Ilir Timur II. Teknik penentuan sampel informan menggunakan purposive sampling dimana informan dipilih dengan pertimbangan informan tersebut yang lebih mengetahui terkait data dan informasi yang akan didapatkan.

Teknik Pengumpulan data pada penelitian ini dilakukan dengan empat cara; yaitu Observasi, wawancara mendalam (indepth interview), dokumentasi dan triangulasi data. Observasi dilakukan pada tiga komponen yaitu tempat, pelaku, dan aktivitas. Observasi dilakukan secara pasif dengan melihat aktivitas dan perilaku pelaku UMKM sektor Kuliner di kawasan sentral kampung pempek 26 ilir, sentra Kuliner Sekanak, 27 Ilir dan pelaku UMKM 32 ilir serta Ilir Timur II dalam menjalankan usahanya. Wawancara mendalam dilakukan oleh peneliti dan asisten peneliti terhadap pelaku usaha UMKM dan pelaksana program yang ditunjuk oleh pihak Dinas Koperasi dan UKM Kota Palembang. Wawancara berbentuk semi terstruktur dengan menggunakan pedoman wawancara dan pertanyaan serta dapat dikembangkan sesuai dengan jawaban dari informan.

Untuk mendapatkan keterangan tambahan wawancara juga dilakukan dengan pelaku UMKM yang tidak termasuk kedalam binaan Dinas Koperasi dan UKM Kota Palembang. Dokumentasi diperoleh dari catatan, laporan dan data yang dimiliki oleh Dinas Koperasi dan UKM Kota Palembang, juga dari jurnal dan buku yang relevan dengan penelitian ini. Tahap selanjutnya Triangulasi, yaitu mengecek kebenaran data dengan mencari data pendukung berupa dokumentasi, foto dan laporan kegiatan yang dijalankan oleh komunitas Pelaku UMKM Kota Palembang. Apabila semua data sudah terkumpul, data kemudian diuji kembali dengan mengulang pertanyaan wawancara pada sumber yang berbeda. Setelah data jenuh artinya tidak terdapat perbedaan informasi yang diperoleh maka data sudah bisa dilakukan analisis

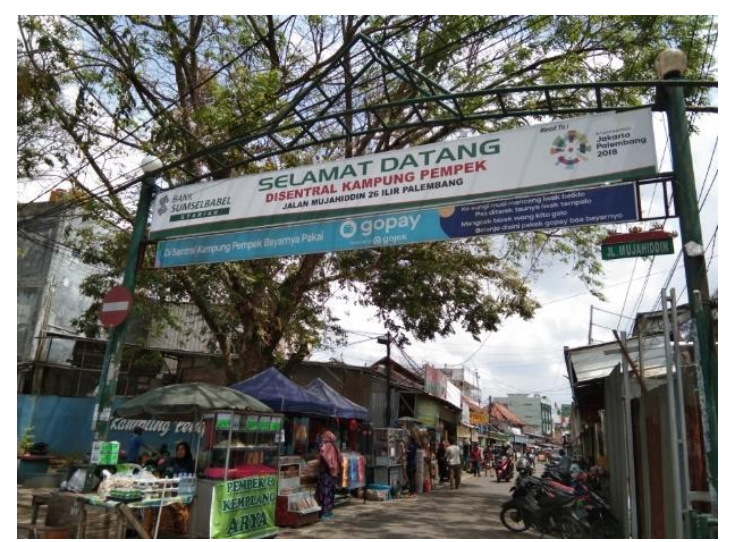

Gambar 1. Sentral Kampung Pempek 26 Ilir, Kota Palembang

Sumber : Dokumentasi Penelitian, 2020

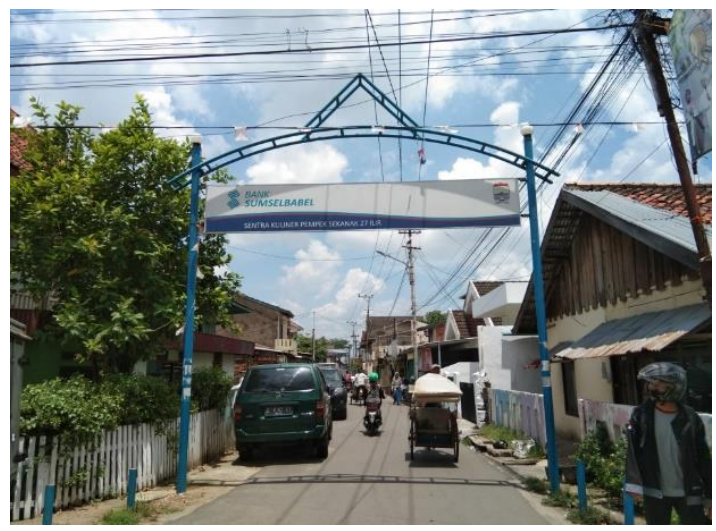

Gambar 2: Sentra Kuliner Pempek Sekanak 27 Ilir, Kota Palembang

Sumber: Dokumentasi Penelitian, 2020

Uji keabsahan data dalam penelitian ini meliputi: uji derajat kepercayaan, keteralihan, kebergantungan dan kepastian (Sugiyono, 2014). Dalam penelitian ini, dilakukan uji keabsahan data yang meliputi; a) Uji kredibilitas, yaitu: Perpanjangan pengamatan penelitian (triangulasi data), dilakukan untuk mengecek kembali kebenaran data dan informasi yang diberikan terdahulu dengan asumsi bahwa hubungan peneliti dan informan dapat semakin akrab sehingga relatif sedikit informasi yang disembunyikan karena sudah tumbuh kepercayaan, sehingga akan didapat analisis lebih mendalam terhadap hasil penelitian.

Perpanjangan pengamatan triangulasi yang dilakukan dalam penelitian disini yaitu 
triangulasi sumber, dan triangulasi teknik pengumpulan data. Menggunakan referensi yaitu instrumen pendukung keabsahan data yang ditemukan peneliti misalnya alat perekam dan kamera. Mengadakan member check, yaitu dilakukan dengan mengecek ulang garis besar informasi yang telah diperoleh dari informan pada setiap akhir wawancara. b) Keteralihan, didasarkan pada pengetahuan penulis dari hasil membaca berita dari website atau bahan berupa dokumen sekunder dan laporan program, pengetahuan tersebut dijadikan sebagai bahan cross check terhadap data yang diperoleh terkait dengan penelitian akan dilakukan c) Kebergantungan, dilakukan untuk memastikan apakah hasil penelitian ini benar atau salah, penulis membahas dengan beberapa rekan kerja sesama dosen yang memiliki bidang/disiplin ilmu yang sama dan kompeten dibidangnya kemudian menuangkan ke dalam tulisan artikel.

Metode analisis data yang digunakan dalam penelitian ini adalah analisis deskriptif kualitatif. Aktivitas dalam analisis data, berupa reduksi data, penyajian data dan penarikan Kesimpulan(Sugiyono, 2014).

\section{HASIL DAN PEMBAHASAN}

Hasil penelitian menggambarkan tentang implementasi program pembinaan pelaku usaha mikro kecil dan menengah sektor kuliner di Kota Palembang. Pendeskripsian proses implementasi program ini dilihat dengan menggunakan teori Grindle tentang isi kebijakan dan lingkungan kebijakan, selanjutnya pembahasan ini dilakukan secara mendalam berdasarkan indikator-indikator yang telah ditentukan tersebut.

Analisis Isi kebijakan dalam Program Pembinaan UMKM Sektor Kuliner

Keberhasilan Program Pembinaan Pelaku UMKM Sektor Kuliner di Kota Palembang sangat tergantung dengan kebijakan apa yang dipilih untuk mengatasi persoalan yang dihadapi UMKM. Kebijakan yang tepat diperlukan untuk memfasilitasi kebutuhan UMKM dalam rangka eksistensi UMKM sendiri ditengah masyakat terlebih di masa pandemi Covid 19. Hasil penelitian ini menunjukkan persoalan yang dihadapi oleh
UMKM diantaranya penurunan keuntungan yang diperoleh oleh pelaku UMKM sampai dengan tutup beberapa kegiatan usaha. Sehingga, kebijakan yang dikeluarkan pemerintah diharapkan dapat menjadi solusi bagi pelaku UMKM mengatasi kesulitan yang dihadapi. Dukungan pemerintah ini juga sejalan dengan Hasil penelitian (Hutabarat, 2015) yang menyimpulkan bahwa dalam pengembangan usaha UMKM selain perlu dukungan dari pelaku usaha dan pihak perguruan tinggi juga harus ada intervensi kebijakan dari pemerintah untuk membantu UMKM sektor kuliner ini dapat tumbuh dan berkembang.

Program Pembinaan Pelaku UMKM khusus Sektor Kuliner di Kota Palembang haruslah memfasilitasi kelompok sasaran yaitu pelaku UMKM sendiri, yang menjadi kelompok sasaran dalam program ini adalah Pelaku UMKM sektor kuliner dan pangan baik pangan modern maupun khas tradisional Palembang. Didalam tugas dan fungsinya jelas tertulis tugas bagian pemberdayaan Usaha Mikro salah satunya adalah melakukan pembinaan terhadap UMKM. Karena jumlah UMKM yang cukup besar maka pembinaan tidak langsung ke pelaku usaha namun melalui pendamping dan komunitas yang dipilih oleh Dinas Koperasi dan UKM Kota Palembang. Dengan demikian perlunya penguatan kelembagaan UMKM hal ini dikarenakan belum adanya komunitas kuliner yang memiliki program yang berkelanjutan dalam mendukung dan membina usaha yang sejenis dalam komunitas tersbut, hal ini menunjukan dalam program pembinaan yang dilakukan pemerintah perlu juga adanya penguatan kelembgaan UMKM (Sukoco, 2019), artinya pembinaan yang dilakukan oleh pemerintah Kota Palembang yang lebih penting juga bagaimana kelembagaan UMKM ini kedepan bisa menjadi lebih kuat. Serta perlunya upaya meningkatkan pengetahuan para pelaku UMKM untuk mendorong kelembagaan UMKM agar menjadi lebih kuat (Indra, 2014)

Selain pembinaan secara individu Pembinaan yang lebih efektif dilakukan terhadap organisasi atau kelompok masyarakat (Thoha, 1997) Pembinaan dilakukan terhadap komunitas untuk 
kemudian komunitas tersebut yang akan bergerak melakukan pembimbingan terhadap pelaku usaha yang menjadi anggotanya. Komunitas UMKM yang dibina oleh Dinas Koperasi dan UKM terdiri dari 6 komunitas yang berbeda sector, diantaranya; sektor kuliner, craft, rajut, songket, kayu dan lain-lain namun dalam penelitian ini difokuskan pada komunitas UMKM sektor kuliner. Pembinaan dilakukan melalui pelatihan pengemasan produk, pemberian modal usaha, dan penyediaan stand pameran. Untuk dapat dibina maka terlebih dahulu pelaku UMKM harus bergabung dalam komunitas.

Persyaratan khusus yang harus dipenuhi oleh kelompok sasaran untuk mendapatkan pembinaan berupa modal usaha diantaranya; kartu keluarga dan kartu tanda penduduk, akta nikah, rekening listrik, Surat keterangan usaha (SKU) dari kelurahan, rekomendasi Camat, surat pengantar Camat ke dinas, formulir aplikasi bank dan foto tempat usaha.

Dalam pembinaan yang dilakukan terhadap pelaku UMKM terdapat beberapa manfaat yang diperoleh pelaku UMKM diantaranya pemberian pinjaman tanpa bunga, tanpa agunan, pemberian pelatihan kepada komunitas UMKM, dan bantuan hibah yang diberikan kementerian koperasi dan UKM. Hal ini juga disampaikan oleh masyarakat yang mendapat binaan Dinas Koperasi dan UKM, bahwa mereka mendapatkan pelatihan dan modal usaha kredit tanpa bunga dan agunan. Pemberian bantuan berupa pelatihan dan modal usaha tersebut hendaknya juga dilkakukan upaya pengawasan dan pendampingan terkait dengan ketepatan penggunaan modal usaha dan kemampauan pelaku UMKM untuk meningkatan nilai dan daya saing produknya (Kartika et al., 2020)

Perubahan yang dirasakan oleh pemilik usaha terutama saat pandemi covid 19 , sangat terasa. Oleh karena itu, bantuan modal yang diberikan pemerintah sangat diharapkan. Dengan modal tersebut mereka bisa tetap menjalankan usahanya. Berbeda dengan pelaku usaha yang tidak mendapatkan binaan, mereka harus berjuang sendiri. Beberapa diantara mereka merasakan penurunan omset sampai dengan 60-80 \% (Irawan, 2020) bahkan ada yang berganti usaha atau malah menutup usahamya.

Bagi pelaku usaha yang mendapatkan binaan bantuan modal dapat mengembangkan usaha dan melalui pelatihan terjadi peningkatan pengetahuan dan perbaikan kualitas produk kuliner yang mereka jalankan. Secara ekonomi manfaat yang diperoleh berupa perluasan usaha sedangkan secara sosial pembinaan membuat mereka aktif tergabung dengan komunitas dan dapat berbagi pengalaman dengan yang lain dalam menjalankan usahanya. Selain sebagai sarana memperoleh informasi komunitas juga dapat menjadi ajang promosi dalam memperkenalkan produk yang mereka miliki dan memiliki inovasi yang digerkan oleh pemerintah (Kurniawan, 2017).

Sasaran program ini pada dasarnya sudah dapat dikatakan tepat dari sisi pelaksana pembuat kebijakan dan penerima program terutama program bantuan yang sudah dijalankan sejak 2017 sampai dengan 2019. Namun, di tahun 2020 terjadi refocusing anggaran, anggaran pemberian kredit dan program pelatihan dialihkan untuk anggaran penuntasan covid 19 sehingga di tahun ini pelatihan ditiadakan. Sehingga jumlah pembinaan tidak dapat ditambah. Anggaran bantuan kredit agak menurun. Sasaran program ini adalah masyarakat pelaku UMKM yang tergabung dalam komunitas yang telah memenuhi syarat yang ditentukan oleh Dinas Koperasi dan UKM.

Dalam pelaksanaan program ini dijelaskan tahapan proses pemberian bantuan dana pembinaan. Dalam proses pemberian bantuan pinjaman dinas menetapkan program pembinaan, kemudian menyebarkan informasi dan melakukan pengumpulan data sasaran penerima program, lalu pihak bank melakukan verifikasi data dan kelayakan penerima program. Selanjutnya, pelaku usaha membentuk komunitas UMKM dan pihak Dinas mengutus pendamping dari pihak professional untuk membantu pendampingan dan sosialisasi, dilanjutkan 
dengan pelaksanaan kegiatan pelatihan agar kegiatan tersebut dapat tepat sasaran (Marlinah, 2020).

Dalam program pembinaan ini terutama dalam program pembinaan melalui bantuan pinjaman, SDM yang mengurusi bidang UMKM bekerjasama dengan Bank pemberi pinjaman. Dalam pelaksanaan pembinaan berupa pelatihan, SDM bidang UMKM dibantu oleh dua orang pendamping dari organisasi professional. Terbatasnya tenaga SDM ini menjadi hambatan dalam pelaksanaan program pembinaan karena jumlah UMKM yang sangat banyak hanya diurus oleh 2 tenaga pendamping, akibatnya belum semua UMKM dapat difasilitasi. Oleh karena itu, perlu adanya tambahan pendamping kegiatan pelatihan bagi pelaku UMKM (Hardilawati, 2020).

Disamping itu dalam pembinaan ini, peran komunitas sangat penting sebagai penyampai informasi dalam pembinaan yang dilakukan oleh Dinas Koperasi dan UKM bagi pelaku UMKM di Kota Palembang.

Analisis lingkungan kebijakan dalam program pembinaan UMKM sektor Kuliner

Program pembinaan pelaku UMKM di Kota Palembang didukung oleh program bantuan kredit tanpa agunan dan tanpa bunga yang dikeluarkan oleh pemerintah Kota Palembang. Sehingga program pembinaan yang dilakukan dapat bersinergi dengan program utama pemerintah Kota Palembang. Program pembinaan ini dilakukan secara berkelanjutan, selama masih banyak UMKM yang membutuhkan pembinaan yang dilakukan bersinergi dengan pihak lain(Hanoatubun, 2020)

Strategi pembinaan juga dilakukan dengan mengajak para pihak terutama BUMN untuk mendukung program pemerintah untuk meningkatkan kualitas UMKM (Hutabarat, 2015). Capaian pembinaan selama ini masih sangat minim menuntut peran dari berbagai pihak untuk membantu dalam pembinaan UMKM ini terutama dari BUMN atau BUMD yang memiliki dana CSR seperti bank mandiri, Bank BRI Syariah, Bank Sumselbabel dan bank lainnya. Pembinaan pelaku UMKM juga diarahkan untuk mendapatkan bantuan wirausaha pemula dari Kementerian Koperasi dan UKM.

Disamping itu, dukungan dari pelaku UMKM yang tergabung dalam komunitas dapat menentukan keberhasilan program pembinaan pelaku UMKM terutama sektor kuliner di Kota Palembang. Komunitas ini juga dapat dibentuk secara mandiri oleh masyarakat ataupun dibentuk dengan pendampingan dari Dinas Koperasi dan UKM. Dinas Koperasi dan UKM telah menyiapkan tenaga SDM dan pendampingan bagi komunitas pelaku UKM tujuannya adalah untuk membantu meningkatkan daya jual dan ekonomi pelaku UMKM. Komitment ini dipertegas dengan dukungan dari pemerintah yang akan menyediakan fasilitas dana modal bagi UMKM.

Selain itu, program pembinaan ini juga bersinergi dengan program dari Dinas Pariwisata, dalam hal promosi kuliner, juga dengan Dinas perikanan dan kelautan untuk nilai gizi yang terkandung di dalam bahan mentah kuliner khas Kota Palembang. Dinas Koperasi dan UMKM Provinsi Sumatera Selatan, Kementerian Koperasi dan UMKM RI dan Program CSR dari Perusahaan atau Bank.

Kelompok sasaran dalam hal ini pelaku UMKM sangat mendukung program pembinaan ini terutama karena manfaat yang dirasakannya. Para pelaku UMKM berharap jumlah pinjaman lebih diperbesar agar dapat meningkatkan modal usaha terutama untuk meningkatkan kualitas alat dan bahan baku produksi. Disamping itu pelaku UMKM berharap pelatihan yang diberikan dapat diberikan secara merata kepada semua pelaku UMKM yang membutuhkan pelatihan terutama untuk sektor kuliner disebabkan oleh banyaknya pelaku usaha yang belum memahami cara pengurusan produk halal, atau bagaimana cara pengemasan produk yang baik. Dengan demikian program pembinaan yang dilakukan pemerintah memiliki relevansi dalam peningkatan pengetahuan dan peningkatan produk pelaku UMKM (Sukoco, 2019)

Disamping respon positif tersebut ada juga pelaku UMKM yang tidak terlalu berharap mendapatkan pembinaan hal ini dikarenakan proses pemberian bantuan yang dianggap rumit dikarenakan syarat 
yang ditetapkan dianggap terlalu berbelitbelit, mereka tidak mau direpotkan dengan pengurusan administrasi dan perizinan, untuk mengatasi kondisi seperti ini sosialisasi dan penyampaian informasi oleh Dinas Koperasi dan UKM sangat diperlukan. Strategi mengatasi hambatan dalam pelaksanaan Program Pembinaan UMKM di Kota Palembang

Hasil temuan penelitian menunjukkan masih terdapat hambatan yang dihadapi dalam Implementasi program pembinaan pelaku UMKM ini. Hasil penelitian Agusetyaningrum terdapat beberapa Hambatan dalam pengembangan UMKM dapat juga berupa permodalan, bahan baku, peralatan, SDM dan lahan (Agusetyaningrum et al., 2016)

Program Pembinaan ini dapat dioptimalkan dengan menggunakan strategi/cara diantaranya; pertama, Sosialisasi berkelanjutan kepada komunitas Pelaku UMKM, hal ini dilakukan agar mereka memahami manfaat pembinaan dan mau bergabung dalam komunitas pelaku Usaha yang dibentuk. Kedua, Melibatkan Peran/ keterlibatan multi sektor dalam pelatihan dan pembinaan sektor kuliner baik dari perusahaan maupun akademisi. Ketiga, mempermudah proses dan persyaratan pengajuan kredit tanpa agunan, dan menambah jumlah sasaran penerima bantuan kredit. Keempat, perlu riset gabungan antara berbagai pihak dalam mengenalkan inovasi teknologi baru untuk meningkatkan kualitas produk dan daya saing UMKM sektor kuliner, baik dalam rasa maupu pengemasan. Kelima, menambah sumber daya pelaksana sebagai pendamping dalam program pembinaan, bisa dengan melibatkan peran perguruan tinggi menggunakan sarana kegiatan riset maupun pengabdian masyarakat(Amri, 2020) . Faktor penghambat tersebut juga dapat diatas bila program pembinaan pemerintah telah dilaksanakan dengan baik dan dengan faktor pendukung yang sejalan dalam pembinaan yaitu berupa dukungan perizinan, pelatihan pemasaran dan penguyuban pelaku UMKM.

\section{SIMPULAN}

Hasil penelitian menunjukkan Implementasi program pembinaan pelaku UMKM sektor kuliner di Kota Palembang, sudah dapat dikatakan cukup baik, namun belum optimal, kondisi ini dapat dilihat dari masih adanya hambatan yang dihadapi dalam Implementasinya. Program pembinaan ini masih dapat dioptimalkan dengan menggunakan berbagai strategi. Dengan penerapan strategi-strategi ini, pelaksana program pembinaan UMKM pemerintah Kota Palembang dapat mengatasi hambatan yang menjadi persoalan dalam pelaksanaan Program pembinaan UMKM di Kota Palembang.

\section{UCAPAN TERIMAKASIH}

Penelitian ini tidak dapat terlaksana dengan baik dan lancar tanpa bantuan dari pihak-pihak terkait, oleh karena itu kami mengucapkan terima kasih kepada Rektor Universitas Sriwijaya, Lembaga Penelitian dan pengabdian Masyarakat (LP2M) Universitas Sriwijaya, yang telah memberikan dana Hibah untuk pelaksanaan penelitian ini, Kepala Dinas Koperasi dan UKM Kota Palembang beserta Staf, Komunitas pedagang Pempek, dan para Informan atau narasumber yang telah bersedia diwawancarai juga pihak-pihak lain yang tidak bisa kami sebutkan satupersatu.

\section{DAFTAR PUSTAKA}

Agusetyaningrum, V., Mawardi, M., \& Pangestuti, E. (2016). Strategi Pengembangan Usaha Kecil dan Menengah (UKM) Untuk Meningkatkan Citra Kotan Malang Sebagai Destinasi Wisata Kuliner (Studi Pada Ukm Berbasis Kuliner Kota Malang). Jurnal Administrasi Bisnis S, 38(2), 105-111.

Agustin, F. M. (2020). Ini Faktor Penyebab Target Binaan UMKM Kota Palembang Belum Tercapai. IDN Time.

Amri, A. (2020). Dampak Covid-19 Terhadap UMKM Di Indonesia. JURNAL BRAND, 2(1), 123-130.

Dewi dan Nasution, S. A., \& Hakim. (2013). Peranan Kredit Usaha Rakyat (KUR) Bagi Pengembangan UMKM Di Kota Medan (Studi Kasus Bank BRI). Jurnal Ekonomi Dan Keuangan, 1(3), 105-116. 
Hamzah Lies Maria \& Agustien Devi. (2019). Pengaruh Perkembangan Usaha Mikro, Kecil, Dan Menengah Terhadap Pendapatan Nasional Pada Sektor Umkm Di Indonesia. Jurnal Ekonomi Pembangunan, 8(2), 215-227.

Hanoatubun, S. (2020). Dampak Covid-19 Terhadap Perekonomian Indonesia. EduPsyCouns: Journal of Education, Psychology and Counseling, 2(2), 146153.

Hardilawati, W. laura. (2020). Strategi Bertahan UMKM di Tengah Pandemi Covid-19. Jurnal Akuntansi Dan Ekonomika, 10(1), 89-98. https://doi.org/10.37859/jae.v10i1.1934

Hutabarat, L. R. F. W. M. (2015). Strategi Pengembangan Usaha Kuliner di Kota Malang Berbasis Ekonomi Kreatif. Jurnal Ekonomi Dan Studi Pembangunan, 7(1), 12-20.

Indiahono, D. (2017). Kebijakan Publik Berbasis Dynamic Policy Analysis. Penerbit Gava Media.

Indra, S. (2014). Kelembagaan Usaha Mikro Kecil dan Menengah dan Pembangunan Ekonomi Masyarakat. Journal of Applied Business and Economics, 1(1), 122-133.

Kartika, C., Rudiatno, R., \& Suhariningsih, L. (2020). Pengelolaan dan Pembinaan Usaha Mikro Warung Makanan dan Minuman Model Primitive Di Surabaya Barat. Humanism: Jurnal Pengabdian Masyarakat, 1(2), 93-108. https://doi.org/10.30651/hm.v1i2.5378

Kurniawan, R. C. (2017). Inovasi Kualitas Pelayanan Publik Pemerintah Daerah. Fiat Justisia, 10(3), 569-586. https://doi.org/10.25041/fiatjustisia.v10 no3.794

Lili Marlinah. (2020). Peluang dan Tantangan UMKM Dalam Upaya Memperkuat Perekonomian Nasional Tahun 2020 Ditengah Pandemi Covid 19. Jurnal Ekonomi, 22(2), 118-124.

Miftha Thoha. (1997). Pembinaan Organisasi. Rajawali.

Palembang, D. K. \& U. K. (2019). Data UMKM dan Koperasi Palembang Tahun 2019.

Rakib Muhammad Alyas. (2017). Strategi Pengembangan Usaha Mikro, Kecil Dan Menengah Dalam Penguatan Ekonomi Kerakyatan. Jurnal Sosiohumaniora, 19(2), 114-120.

Suci, Y. R., Tinggi, S., \& Ekonomi, I. (2017). Perkembangan UMKM (Usaha Mikro Kecil Menengah) di Indonesia. Jurnal Ilmiah Cano Ekonomos, 6(1), 51-58.
Sugiri, D. (2020). Menyelamatkan Usaha Mikro, Kecil dan Menengah dari Dampak Pandemi Covid-19. Fokus Bisnis: Media Pengkajian Manajemen Dan Akuntansi, 19(1), $\quad$ 76-86. https://doi.org/10.32639/fokusbisnis.v1 9i1.575

Sugiyono. (2014). Metode Penelitian Kuantitatif, Kualitatif dan R \& D. Alfabeta.

Sukoco, J. B. (2019). Kapasitas Kelembagaan Dalam Pembinaan Usaha Mikro Kecil Dan Menengah Di Kota Surakarta. Jurnal Administrasi Bisnis, 8(1), 15-22. https://doi.org/10.14710/jab.v8i1.21215

Trisnawati. (2016). Kajian Inovasi Sektor Usaha Kecil menengah (UKM) dengan Pendekatan Sistem Dinamis (Studi Kasus pada Industri Makanan di Kabupaten Sidoarjo Jawa Timur). Jurnal Akuntansi, Ekonomi, Dan Manajemen Bisnis, 4(1), 6067. 